\title{
Group sweeping: Feeding activity and filtration rate in the tubiculous amphipod Haploops nirae (Kaim-Malka, 1976)
}

\author{
Carinne Rigolet ${ }^{\mathrm{a}, \mathrm{c}}$, Pierrick Le Souchu ${ }^{\mathrm{b}}$, Xavier Caisey $^{\mathrm{a}}$, Stanislas F. Dubois ${ }^{\mathrm{a}, \text { * }}$
}

\author{
${ }^{a}$ IFREMER Benthic Ecology Laboratory - Technopole Brest-Iroise BP70, 29280 Plouzane, France \\ b IFREMER Station Expérimentale d'Argenton - Presqu'île du Vivier, 29840 Argenton, France \\ c Université Pierre et Marie Curie - Station Biologique de Roscoff UMR 7144, BP74, 29682 Roscoff Cedex, \\ France
}

\author{
*: Corresponding author: Stanislas F. Dubois, Tel.: + 33298224918 ; fax: + 33298224548 ; \\ email address : sdubois@ifremer.fr
}

\begin{abstract}
:
Haploops nirae is a gregarious tubiculous amphipod that uses its two pairs of antennae to filter particles from the water column. Recent sonar mappings of Haploops seabeds revealed that thousands of hectares of soft-bottom muddy sediments in South Brittany coastal ecosystems are now colonized by this amphipod. The present study investigates (1) the structure of the feeding organs and the mechanisms involved in particle capture, (2) the effect of environmental parameters (current velocity, turbidity and food concentration) on the feeding activity of $H$. nirae, quantified by the percentage of active individuals, the frequency of antennae beats and the number and duration of feeding events and (3) the retention efficiency and clearance rate of $H$. nirae individuals, so extrapolation to colonized areas and grazing impact of this species can be estimated. Staining techniques and scanning electron microscopy revealed that Haploops antennae have a more complex structure than congeneric Ampelisca species, involving long setae bearing short setules and that mucus is involved in particle capture. An increase in current velocity seemed to have very little effect on feeding activity but unexpectedly slightly increased the frequency of antennae beats. However, an increase in both organic and inorganic matter both exponentially increased the number of filtering individuals and showed that Haploops are well adapted to feed in turbid conditions: the total time individuals spent filtering remained constant while inorganic particulate matter increased from 10.7 to $85.6 \mathrm{mg} \cdot \mathrm{L}^{-1}$. Using a flow-through system, evaluation of retention efficiency showed that only particles larger than $20 \mu \mathrm{m}$ equivalent spherical diameter were 100\% retained by feeding structures, which corresponds to the mean distance between two setules. Clearance rate was estimated at $14.6 \pm 0.4 \mathrm{~mL} \cdot \mathrm{h}^{-1} \cdot \mathrm{ind}^{-1}$ or standardized to $25.2 \pm 0.7 \mathrm{~L} \cdot \mathrm{h}^{-1} \cdot \mathrm{g}^{-1}$ dry weight. Those values are discussed in light of values obtained in other suspension-feeding species and also extrapolated to the whole Haploops community. We estimated that Haploops have the capacity to filter the entire water column in $4-5$ days and a volume of water equivalent to the whole bay in 29-30 days. This study provides evidence that changes in the spatial extent of Haploops communities may have serious impacts within coastal ecosystem they have colonized.
\end{abstract}

\section{Highlights}

- We investigated feeding ecology of crustacean tubiculous amphipod Haploops nirae. Retention efficiency showed that particles larger than $20 \mu \mathrm{m}$ ESD were $100 \%$ retained. The individual clearance rate was $14.6 \pm 0.4 \mathrm{~mL} \cdot \mathrm{h}^{-1}$. ind ${ }^{-1}$ or $25.2 \pm 0.7 \mathrm{~L} \cdot \mathrm{h}^{-1} \cdot \mathrm{gdw}^{-1}$. The feeding activity revealed an adaptation to feed under turbid conditions. Haploops filter a volume of water equivalent to the whole bay in $29-30$ days. 
Keywords: Amphipods ; Ampeliscidae ; Clearance rate ; Gregarious suspension-feeders ; Grazing impact ; Retention efficiency ; South-Brittany

\section{Introduction}

The tube-building amphipod Haploops nirae (Kaim-Malka) is a gregarious species that inhabits shallow coastal waters and belongs to one of the largest amphipod families Ampeliscidae. Ampeliscids are classified as suspension-feeders but differences occurred between genera even if all species share a common feature of lying in a U-shaped bend in their silty tube with the ventral side uppermost and collect particles from the surrounding water by sweeping their antennae (2 pairs) in the water column (Enequist, 1949). Ampelisca species are known to leave their tube and migrate in the water column (Dauvin and Zouhiri, 1996) and also forage in the sediment by scraping freshly sedimented organic matter. Haploops species are all strictly tubiculous and unlike congeneric Ampelisca species, individuals only leave their tube in exceptional cases. They are hence most likely strictly suspension-feeders (Enequist, 1949). However, most of the knowledge on ampeliscid feeding ecology is based on qualitative observations and to our knowledge, very little is known about the filtration rate and the filter-feeding activity of Haploops species.

Ampeliscidae in general and Haploops species in particular comprise several gregarious species capable of colonizing large areas with densities over a thousand individuals per square meter (Bellan-Santini and Dauvin, 1989). In specific environmental conditions, Haploops or Ampelisca species similarly carpet the seabed with silty-tubes protruding several centimeters above the sediments. When colonizing extensive surfaces, dense tubiculous mats can deeply modify biological and physical processes at sediment-water interface. Dia et al. (2008) showed that dense tube mats formed by Ampelisca spp. improve benthic habitat quality by 
processing large amount of particulate organic matter, and reworking the sediment thereby promoting increased oxygenation of interstitial space. It has also been suggested (Mackenzie et al. 2006) that dense tubiculous amphipods colonies of Ampelisca cover and stabilize sediments, thereby minimizing the transport of silt, and facilitating the colonization and the development of suspension-feeding species. Haploops species have been reported to cover extensive areas in subtidal shallow muddy areas in the bay of Fundy, Canada (Wildish and Dickinson, 1982), in Øresund, Sweden (Göransson, 2002) and in several bays of South Brittany, France (LeBris and Glémarec, 1995). A recent mapping survey revealed that Haploops communities from South Brittany extended more that 12000 hectares (Ehrhold et al., 2006), with densities exceeding 10000 individuals. $\mathrm{m}^{-2}$ (Rigolet, Unpublished results). As part of a larger project designed to understand the functioning of Haploops habitats in coastal ecosystems, the ecological role of Haploops communities as a biological filter must be first addressed. The aim of this study was hence (1) to describe the filtering structures of Haploops species, (2) to evaluate the clearance rate and retention efficiency of Haploops individuals, and (3) to quantify the feeding activity of Haploops and to determine how environmental parameters (current velocity, concentration of food particles, turbidity) affect the feeding behavior of this species.

Complementary approaches using unique mesocosm flow-through systems were deployed to address those questions and extrapolate filtration rate to ecosystem level. This investigation provides a first estimate of ecosystem-level grazing impact of Haploops individuals to determine if the filtering activity of this tubiculous amphipod species, currently spreading in

90 South Brittany, may be of significant importance.

\section{Materials and methods}

\subsection{Amphipod collection, maintenance and experimental setup}

Haploops nirae (Kaim-Malka) were collected in the bay of Concarneau (South Brittany, France, 47 $47^{\prime} 632 \mathrm{~N} ; 3^{\circ} 54^{\prime} 369 \mathrm{E}$ ) in February 2009 by divers at ca. 30 meters depth using 30 $\mathrm{cm}$ deep cylindrical plastic cores. Care was taken to ensure that core surfaces $\left(113 \mathrm{~cm}^{2}\right)$ were undisturbed while sampling. Time from core extraction and removal to temperaturecontrolled laboratory conditions was less than an hour. A new system was created to avoid disturbing the sediment while manipulating Haploops tubes (Fig. 1): individual cores were 
placed on an adjustable piston pin and pushed up, so that the sediment surface reached the top of the core. Once in optimal position, the core was placed in a 6 liter tank and a partition plate inserted at the top of the plastic core, creating a 1.5 liter flow-through chamber (i.e. the volume used for filtration measurements) that was disconnected from the rest of the tank, while keeping the whole core under water. Prerequisites for using flow-through chambers (influence of chamber geometry, recirculation etc.) were tested according to recommendations by Riisgård (2001). The whole experimental setup was similar to previous work with

110 tubiculous worms (Dubois et al., 2009) and consisted of 3 experimental troughs and 1 trough containing a sedimentation control connected in parallel to a continuous supply of filtered and sterilized seawater (temperature $12^{\circ} \mathrm{C}$, salinity 34.5 ). A mixture of several microalgal species were used, so that a broad range of particle sizes was covered (Table 1). The flow rate was adjusted with Gilmont $\subset$ flow-meters with a precision of $2 \mathrm{~mL} \cdot \mathrm{min}^{-1}$ (under 1 atm at $20^{\circ} \mathrm{C}$ ).

115 Haploops individuals were acclimated 48 hours before beginning an experiment. During the acclimation period, attention was paid to remove associated burrowing species (e.g. small bivalves, polychaetes, nemerteans or other crustaceans) found in the sediment between tubes, to avoid physical disturbances and to assure that the measured filtration was only due to Haploops individuals.

\subsection{Description of filtering structures}

Along with core samples, some individuals were collected and extracted from their tube, then washed in filtered seawater to remove mud particles. They were narcotised with increasing 125 concentrations of $7.5 \% \mathrm{MgCl}_{2}$ in filtered seawater $(63 \mu \mathrm{m})$ and placed in a solution of $2.5 \%$ glutaraldehyde in a slightly hyperosmotic, $0.1 \mathrm{M}$ sodium cacodylate buffer (Beninger et al. 1995). An alternative method to the critical point drying (CPD) technique (Boyde and Wood 1969) was used for SEM preparation, consisting of airdrying of specimens by the evaporation of hexamethyldisilazane (HMDS). HMDS has been evaluated as better than CPD for SEM

130 observations of many biological samples (e.g. Hochberg and Litvaitis 2000). Photographs were obtained with the FEI Quanta ${ }^{\mathrm{TM}} 200$ of the Brittany IFREMER Research Center. Additional measurements were performed on freshly narcotized specimens, using a microscope with a calibrated optical scale, in order to assess artefactual shrinkage due to this technique. All measurements made on SEM preparations have been corrected in this manner.

135 To determine if mucus is involved in particle capture in Haploops, narcotized specimens were placed in aqueous Bouin's fixative (Martoja and Martoja 1967). Whole bodies were 
embedded in paraffin and processed histologically as developed for mucocyte secretions (mucopolysaccharides, MPS) in bivalves (Beninger et al. 1996) or polychaete worms (Dubois et al., 2005). Thick transverse and longitudinal sections $(6 \mu \mathrm{m})$ were stained in periodic acid-

140 Schiff-Alcian blue (PAS-AB). Entire antennae and body portions sectioned under a dissecting microscope were placed in staining capsules as well. According to their degree of acidity, acid MPS are PAS-negative and AB-positive, and present high viscosity, whereas neutral MPS are PAS-positive and AB-negative, and present low viscosity.

\subsection{Determination of the retention efficiencies and clearance rate}

To assess retention efficiencies, particle size distributions were determined using a Multisizer 3 particle counter (Beckman Coulter Electronics) fitted with $100 \mu \mathrm{m}$ apertures, with coefficients of coincidence $<5 \%$. All particle sizes were expressed as equivalent spherical

150 diameter (ESD). Particle concentrations were estimated for a size range of 1.8 to $40 \mu \mathrm{m}$ ESD and also represented as particle volume (in $\mathrm{mm}^{3} \cdot \mathrm{mL}^{-1}$ ), as volume provides a better proxy of food quantity. Retention efficiencies (Er) were computed for this entire size range as: $\operatorname{Er}(\%)$ $=100 \times[$ (inflow - outflow $) \times$ inflow $\left.^{-1}\right]$, where inflow represents particle concentration in the control and outflow is particle concentration in the troughs containing the animals. Details of

155 Er calculations are given in Barillé et al. (1993). Er data were used to take into account possible underestimation of clearance rate $(\mathrm{CR})$, due to small particles passing through the filtering structures without being retained and hence released into the chambers with the outflow (Barillé et al, 2006; Dubois et al., 2009). Thus, given the mean flow in an individual trough, CR $\left(1 . h^{-1}\right)$ was calculated as [(inflow - outflow $) \times$ inflow $\left.^{-1}\right] \times$ flow rate, using particles

160 above a threshold that ensured all cleared with 100\% efficiency (Jørgensen et al., 1984). During all CR experiments, flow was kept constant at $2.7 \mathrm{~L} . \mathrm{h}^{-1}$ (or $0.95 \mathrm{~cm} . \mathrm{s}^{-1}$ ). After completion, all individuals were sacrificed in $4.5 \%$ formalized seawater. All tubes were opened and individuals collected, counted and weighted after drying for $48 \mathrm{~h}$ at $60{ }^{\circ} \mathrm{C}$.

\subsection{Determination of feeding activity}

As a proxy to estimate the feeding activity of Haploops, the number of individuals actively filtering, i.e. with antennae in the water column, was determined by monitoring the core surface with a high resolution CCD camera $\left(6.10^{6}\right.$ pixels $)$ mounted on a frame to record the

170 entire core surface. The experimental room was completely isolated from noises and possible 
vibrations, and kept at a constant temperature $\left(12^{\circ} \mathrm{C}\right)$ with a low luminosity, approximating the luminosity measured at 30 meters depth where the Haploops individuals were collected. The camera was connected to a laptop and was remotely controlled with Nikon Camera Control Pro ${ }^{\mathrm{TM}}$. Each experiment was conducted over 6 hours while high resolution pictures 175 were taken every 3 minutes (120 pictures total for each experiment). Haploops tubes were mapped on the first picture and then each picture was analysed using Adobe Photoshop $\mathrm{CS} 3^{\mathrm{TM}}$ to count and map open tubes (i.e. filtering activity) and closed tubes (i.e. no filtering activity).

Besides the total number of filtering individuals, 15 tubes were randomly selected and monitored over the course of each experiment, assuming that the feeding activity status (filtering or non-filtering) of individuals for one snapshot remains the same until the following snapshot (3 minutes). Several individual parameters were then determined, as (1) the mean time of filtering activity, (2) the number of feeding events (a feeding event began when an individual deployed its antennae and ended when it withdrew into its tube), (3) the mean time of a filtering event and (4) the frequency of the antennae beats per minute, recorded visually with hand-counters.

All the experiments designed to test environmental factors are listed in Table 2. Food (e.g. microalgae) was provided using peristaltic pumps with a pure culture of the diatom Thalassiosira weissflogii. The cell concentration was determined using a Malassez cell counting chamber and the relationship between $\mathrm{Chl} a\left(\mu \mathrm{g} \cdot \mathrm{L}^{-1}\right)$ and cell concentration $\left(\mathrm{C}_{\mathrm{c}} 10^{3}\right.$ cell. $\mathrm{mL}^{-1}$ ) was Chl $a=2.7$ x Cc (Møller and Riisgård, 2006). To mimic an increasing range of particulate inorganic matter (hereafter PIM), silt (Kaolinite BS1, AGS Montguyon, France) was added to the diet. Water samples were collected and filtered on pre-weighed GF/F filters dried at $60^{\circ} \mathrm{C}$ for $24 \mathrm{~h}$, so that the amount PIM in the diet was obtained.

195 Several preliminary runs were carried out to verify that no significant differences existed in feeding activity between 12 hour and 6 hour experiments or between full day light and low light intensity. Because of light penetration issues in the water, only the experimental conditions with particulate inorganic matter $(\mathrm{PIM}) \leq 85.5 \mathrm{mg} . \mathrm{L}^{-1}$ enabled a reliable detection of filtering individuals. The counting of beat frequency was not possible for PIM $>23.3$

200 mg. $\mathrm{L}^{-1}$. After each experiment, all Haploops tubes were collected, counted and opened to determine the total number of Haploops individuals.

\subsection{Statistical analysis}


One-way repeated measures ANOVA were used to test for differences in clearance rate (CR) values and feeding activity measurements between experimental conditions. Data were accordingly checked for normality and homogeneity of variance. When normality tests failed, non-parametric Friedman repeated measures analyses of variance were used. A significance level of $\mathrm{p} \leq 0.05$ was used in all tests. When significant, pairwise post-hoc comparisons were performed using the Tukey HSD tests for parametric tests and Holm-Sidak method for nonparametric tests. Changes in feeding activity (FA) parameters were fitted against tested environmental conditions (EC) using an exponential decay curve $\mathrm{FA}=\mathrm{FA}_{0}+\underline{\mathrm{a}} \times \exp ^{(-\lambda \mathrm{EC})}$, where $\mathrm{FA}_{0}$ is the asymptotic value of the measured FA parameter, $\mathrm{a}$ is the intercept, and $\lambda$ is the slope. Estimation of $\mathrm{FA}_{0}$, a and $\lambda$ was achieved with Sigmastat ${ }^{\mathrm{TM}} 2.0$ by using the downhill simplex method. All curve fittings between observations and the asymptotic model were tested by analyses of variance $(p \leq 0.05)$.

\section{Results}

\subsection{Description of feeding structures}

When feeding, Haploops nirae used its 2 pairs of antennae (A1 and A2) independently from each other. Antennae A1 was in the middle upright position and used a backwards-forward motion, while the antennae A2 either moved synchronously with A1 or independently sweep sideward. The four antennae of $\underline{H}$. nirae are about as long as the amphipod body and are slightly bent when extended in the water column. Two rows of long setae are attached to each antenna and form an angle of $90^{\circ}$ in the water. Scanning electron micrographs as well as microscope measurements revealed that setae are between 1 and $2 \mathrm{~mm}$ long and irregularly inserted proximally every $150 \mu \mathrm{m}$ and distally every $110 \mu \mathrm{m}$ onto the antenna (Fig. 2A). When extended in the water column, there is very little overlap in the setae and the four antennae form a semi-circular basket. On each setae, two single-rowed pairs of $10 \mu \mathrm{m}$ spinelike setules are inserted. Two setules are positioned at an angle of $90^{\circ}$ and the distance between 2 pairs of setules range from $25 \mu \mathrm{m}$ to $10 \mu \mathrm{m}$ (mean $19.35 \pm 0.34 \mu \mathrm{m}, \mathrm{n}=25$ ) in the proximal and in the distal part of the setae, respectively (Fig. 2B and 2C). In addition, a nonrigid filamentous structure (about $200 \mu \mathrm{m}$ long) is located at each insertion point of setae along the antennae (see details in Fig. 2C). Both pairs of antennae are similarly structured. 


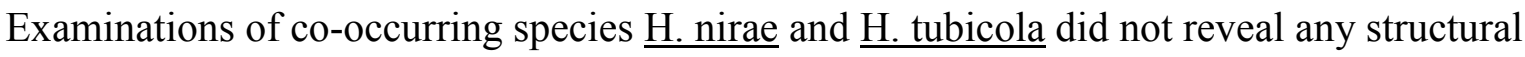
difference, except the total length of antennae, $50 \%$ shorter in $\underline{H}$. tubicola.

Whole-mounts of antennae and longitudinal sections of Haploops individuals stained with periodic acid-Schiff-Alcian blue (PAS-AB) revealed the occurrence of a large acid mucous gland in the propodus of the gnathopod (Fig. 2D). No mucocytes were detected in transversal or longitudinal sections of antennae but large portions of whole mounts antennae were stained in blue, indicating the presence of acid mucus at the surface (Fig. 2E).

245 Additional scanning electron micrographs of several species of Ampelisca (e.g. A. spinipes,

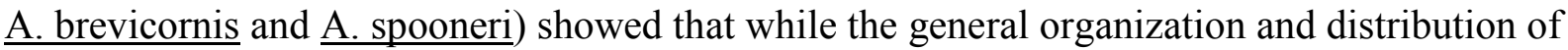
setae seemed similar with the Haploops genus, the setae in Ampelisca species appeared smooth and did not bear setules (see A. spinipes in Fig. 2F).

\subsection{Retention efficiency and clearance rate}

Size spectra obtained with the particle counter - and expressed in ESD showed 4 modes at the inflow and outflow of the experimental troughs (Fig. 3). The first, at around $4 \mu \mathrm{m}$ ESD, was due to Isochrysis galbana (linear length of cells $=5-6 \mu \mathrm{m}$ ), the second, more dispersed and centered around 9-10 $\mu \mathrm{m}$ ESD, was due to Skeletonema costatum which usually form two-cells chains of in batch culture, the third was centered around 13-14 and due to Thalassiosira weissflogii and the forth was centered around 24-25 and due to Scrippsiella trochoidea. In some cases (as the example showed in Fig. 3), particle peaks recorded at the outflow was higher (and broader) than peaks at the inflow (control outflow). This

260 phenomenon is traditionally explained by animal activities which resuspend particles previously deposited and prevent any deposition in the measurement chambers. This phenomenon made the use of a sedimentation control irrelevant in those cases. Each size distribution at the outflow of the troughs was therefore carefully examined prior to retention efficiency calculations and samples with abnormal peaks were discarded. Regardless, inflow

265 of experimental troughs was used instead of outflow of control trough for the calculations. The retention efficiency curve showed an inflection at around $20 \mu \mathrm{m}$ ESD (Fig. 4): all particles larger than $20 \mu \mathrm{m}$ ESD were cleared with 100\% efficiency. Below this size, retention efficiencies decrease rapidly: $80 \%$ of $17 \mu \mathrm{m}$ ESD particles were retained, $50 \%$ of 14

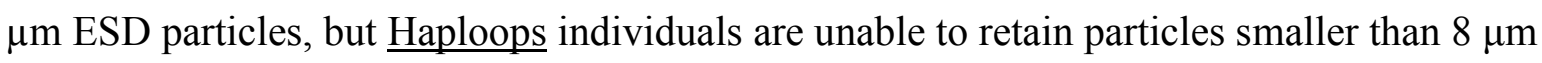
ESD. The clearance rate calculation was therefore based on particles above $20 \mu \mathrm{m}$ ESD, as 
determined by the particle counter, which corresponded mainly to the microalgae $\underline{S}$. $\underline{\text { trochoidea }}$ and a few $\underline{T}$. weissflogii along with long chains of $\underline{\mathrm{S} \text {. costatum }}$ cells.

Comparison of the mean clearance rate (CR) calculated at 3 different times after the beginning of the experiment (60, 90 and 180 minutes) did not reveal any significant statistical differences (Fig. 5, ANOVA, $\mathrm{P}=0.887$ ). A mean clearance rate of $1.06 \pm 0.14 \mathrm{~L}^{\mathrm{h}} \mathrm{h}^{-1}$ was calculated for all data. The mean number of filtering individuals was counted at $78 \pm 9$ individuals. Post-experiment, individual dry weights were measured at $0.578 \pm 0.076 \mathrm{mg}$. Assuming that all the filtering individuals were filtering equally, and that there were no significant differences in individual sizes and weights, the mean clearance rate of an individual was hence estimated at $14.6 \pm 0.4 \mathrm{~mL} \cdot \mathrm{h}^{-1}$. This hypothesis is supported by the low individual dry weight variability and the post-experiment counts showing that only adults occurred at this time of the year (early winter). The standardized clearance rate for Haploops nirae was hence estimated to be $25.2 \pm 0.7 \mathrm{~L} \cdot \mathrm{h}^{-1} \cdot \mathrm{g}^{-1}$ dry weight.

\subsection{Feeding activity}

Effect of current velocity. The mean percentage of filtering individuals varied from $10.6 \%$ $(\mathrm{SE}=0.3)$ for a $13.1 \mathrm{~cm} . \mathrm{s}^{-1}$ flow speed to $21.0 \%(\mathrm{SE}=0.4)$ for a $0.8 \mathrm{~cm} . \mathrm{s}^{-1}$ flow speed. For each flow speed, no significant variations occurred in the mean percentage of filtering individuals during the 6 hours experiments. However, significant differences were detected between the different flow speed conditions (ANOVA, $p=0.003$ ). The highest number of filtering individual occurred for the lowest velocity but no clear pattern can be determined and no fitted model can be satisfactorily applied (Fig. 6). The examination of 15 randomly selected individuals revealed that the mean time Haploops individuals were filtering was 13.6 $\%(\mathrm{SE}=2.9)$ of 6 hours (or about $50 \mathrm{~min}$ ), without significant differences according to flow speed (Table 3). Significant differences were also detected in the mean number of filtration events and the time of each filtration event. Overall, the number of filtration events decreased and the mean time of a filtration event increased as flow speed increase. Antennae beat frequencies showed a large difference: A1 frequency was much slower (between 3 and 7

300 beats. $\mathrm{min}^{-1}$ ) than A2 (between 18 and 30 beats. $\mathrm{min}^{-1}$ ) (Table 3). Statistically, the frequencies of $\mathrm{A} 1$ and $\mathrm{A} 2$ are significantly different for the lowest flow speed and remained slightly higher and constant from 4.4 to $13.4 \mathrm{~cm} . \mathrm{s}^{-1}$. 
Effect of food concentration. For each condition, no significant variations occurred in the 305 mean percentage of filtering individuals during the 6 hours experiments. The total number of filtering Haploops showed highly significant variations according to changes in food concentrations (Chl a) (Fig. 7). The model showed a sharp increase in the percentage of filtering individuals from 2.16 to $13.5 \mu \mathrm{g} . \mathrm{L}^{-1}$ (or $8.10^{2}$ to $5.10^{3}$ cells. $\mathrm{mL}^{-1}$ ) where the percentage reached a plateau (ca. $75 \%$ of individuals were filtering). The percentage $\mathrm{P}$ of

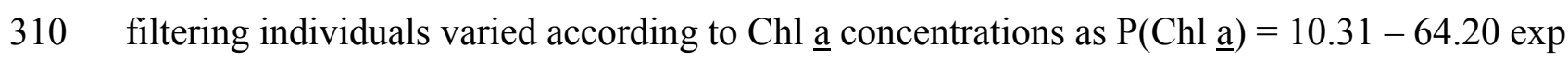
$\left(-3.10^{4} \mathrm{Chl}\right.$ a) (adjusted $\left.\mathrm{r}^{2}=0.925\right)$. Overall, all individual parameters of feeding activity followed the same pattern (Table 4). The total time Haploops individuals spent filtering did not significantly vary between 0 and $2.2 \mu \mathrm{g} . \mathrm{L}^{-1} \mathrm{Chl}$ a $($ mean $=16.3 \pm 5.3 \%$ or ca. $60 \mathrm{~min})$ and sharply increased and plateaued at $83.0 \pm 7.3 \%$ (or $300 \mathrm{~min}$ ) (Fig. 7) as Chl a

315 concentrations reached $13.5 \mu \mathrm{g} \cdot \mathrm{L}^{-1}$. All other measured parameters followed a similar but less pronounced pattern. The mean number and time of filtration events showed an increase in feeding activity, with high inter-individual variability in filtration time when Chl a concentration reached $13.5 \mu \mathrm{g} . \mathrm{L}^{-1}$. The mean time of each filtration event started from 5.2 min up to ca. $30 \mathrm{~min}$ at the plateau (for $\mathrm{Chl}$ a concentration $=13.5 \mu \mathrm{g} . \mathrm{L}^{-1}$ ). The antennae (A1 320 and A2) beat pattern also followed the same increase with a relative sharper increase (4 times, from 2 to 8 beats. $\mathrm{min}^{-1}$ ) for A1 than for A2 (2.5 times, from 15 to 40 beats. $\mathrm{min}^{-1}$ ) when Chl a reached $13.5 \mu \mathrm{g} . \mathrm{L}^{-1}$. The beat frequency ratio A2/A1 consistently decreased from 9 to 4 for the highest $\mathrm{Chl}$ a concentrations.

325 Effect of concentration in inorganic matter (PIM). Silt (Kaolinite) was added in the water until tubes were not easily counted $\left(85.6 \mathrm{mg} . \mathrm{L}^{-1}\right)$. Due to the relative transparency of antennae, counting of their beat frequency was not possible with silt content over $11.0 \mathrm{mg} . \mathrm{L}^{-1}$. For each tested condition from 2.3 to $85.6 \mathrm{mg} . \mathrm{L}^{-1}$, no significant variations occurred in the mean percentage of filtering individuals over the 6 hours experiments. The model (adjusted $r^{2}$ $330=0.945)$ showed that the number of filtering Haploops increased exponentially and closely approximates a $0-1$ response model (Fig. 8). The number of filtering individuals shifted and plateaued from $17 \%\left(2.3 \mathrm{mg} . \mathrm{L}^{-1}\right)$ to $69 \%$ for a silt concentration of $7.3 \mathrm{mg} . \mathrm{L}^{-1}$. From 11.0 to $85.6 \mathrm{mg} . \mathrm{L}^{-1}$, the number of filtering individual remained at the plateau. The total time Haploops individuals spent filtering and the number of feeding events followed the same pattern but the mean time of each feeding event first increased (from ca. 9 to 30 minutes) from $2.3 \mathrm{mg} . \mathrm{L}^{-1}$ to 7.3 and $11.0 \mathrm{mg} . \mathrm{L}^{-1}$ but then significantly decreased to ca. 15 minutes up to $85.6 \mathrm{mg} . \mathrm{L}^{-1}$ (Table 5). The frequency of A1 and A2 beat frequency did not show large 
variations (even though only 3 PIM conditions were available) except for a decrease in A1 frequency for $7.3 \mathrm{mg} . \mathrm{L}^{-1}$. A2 beat frequency remained much higher than A1.

\section{Discussion}

Ampeliscid species - one of the largest amphipod families (Dauvin and Bellan-Santini, 1996) - are known to be both suspension- and deposit-feeders, collecting food particles by scrapping

345 the sediment surface but also by sweeping their two pairs of antennae in the water column (Enequist, 1949). Within this family, while Ampelisca genus exhibits a mix between suspension- and deposit-feeding species with often contradictory statements (Kanneworff, 1966), Haploops species are apparently all suspension-feeders. However, most of the understanding of ampeliscid feeding behavior came from qualitative aquaria experiments and very little detailed information is available. As a model for suspension-feeding ampeliscid, we provided here a better understanding of the filtering structure and feeding behavior of Haploops nirae, as well as an estimate of its clearance rate.

\subsection{Filtering structures and particle capture in Haploops nirae}

A close examination of Haploops nirae filtering structures using complementary approaches (e.g. scanning electron micrographs, histological mucocyte mapping and traditional microscope photographs) revealed that $\underline{\text { Haploops }}$ - both $\underline{\text { H. nirae }}$ and $\underline{H}$. tubicola - antennae bear long setae and that those setae had short spine-like setules. Plumose setae are a common

360 feature in amphipods, and are traditionally found on coxal plates and appendages such as mouthparts, gnathopods, pereopods or pleopods but it has been disregarded in the description of Haploops species (Lincoln, 1979; Dauvin and Bellan-Santini, 1990). No such setules were observed in the 3 Ampelisca species we scanned, and along with the low number of setae on the antennae, this feature could serve as a quick and easy morphological trait in ampeliscid to

365 possibly separate Ampelisca from Haploops species. Similar observations have to be extended to additional species, including the genus Byblis (the third genus belonging to the Ampelicidae family). These differences also have functional consequences for the Ampeliscidae feeding ecology. A 3-dimensional filtering structure offers a much more complex and extended surface to collect particles and is commonly observed in obligatory suspension-feeders (Levinton, 1995). The observed antennae structures provide evidence that

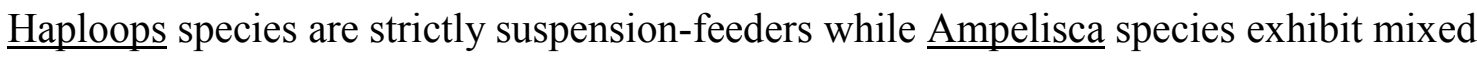


feeding behaviors. These observations also bring new insight into the general behavior of these two genera. Most Ampelisca species are tubiculous species but are known to easily leave their tube and even migrate in the water column (Dauvin and Zouhiri, 1996), hence having access to a large variety of food sources. Haploops rarely leave their tube (Enequist, 1949) and consequently suspended particles are the only food source accessible. The longer and the more setose the antennae, the more area they can subtend and therefore the more water they can potentially filter. Haploops species seemed hence to be more specialized in suspension-feeding than Ampelisca species.

380 For suspension-feeders, mucus plays a primary role in the collection and the transport of food particles, as evidenced in bivalves (e.g. Beninger and Saint-Jean, 1997) or polychaetes (e.g. Dubois et al., 2005). Using staining techniques (PAS-AB techniques), we have demonstrated here that the mucus is also used in suspension-feeding amphipods. To our knowledge, this is the first evidence of crustaceans using mucus in particle capture (see review of Riisgård and Larsen, 2010). Acid (i.e. stained in blue) mucus secretions were detected on Haploops antennae and evidence of a large acid mucus gland was found in the distal region of the gnathopods. Mucus glands have been described in several amphipod species but are mainly associated with the mouthparts and alimentary canal (Shyamasundari and Rao, 1977) and used in tube building (Shillaker and Moore, 1978). We hypothesized here that antennae do not have mucocytes (as showed buy transversal and longitudinal sections) but are coated in mucus by the gnathopods when the antennae are flexed down and then brushed out with the first coxal plates and the gnathopods, before the antennae are redeployed in the water. With this mechanism, particles are stuck with high viscosity, acid mucus to the antennae. Viscous acid or acid-dominant mucopolysaccharides are used on exposed surfaces of feeding structures by other species, such as in the ordinary filament crest of the gill in the scallop Placopecten magellanicus (Beninger et al. 1993), or the frontal filament of the gill in the blue mussel Mytilus edulis (Beninger et al. 1993) exposed to siphonal currents. Polychaetes such as Sabellaria alveolata also use mucus in the frontal surface of tentacles and grooves of that are directly exposed to currents in the water column (Dubois et al., 2005). Particles stuck on

400 Haploops antennae would therefore require a high-viscosity mucus to avoid resuspension. When antennae are spread out in the water column, the setae and the bristles form a net that collect particles larger that $20 \mu \mathrm{m}$, as shown by calculation of retention efficiencies. This calculation is supported by the mean distance between two bristles along the setae (mean $19.35 \pm 0.34 \mu \mathrm{m}, \mathrm{n}=25)$. Because Haploops species only live in muddy habitat, where turbidity is often high (LeBris and Glémarec, 1996), not being able to retain smaller particles 
seems well adapted to this amphipod's ecological constraints. Antennae structures are hence less rapidly saturated by small inorganic particle (2-5 $\mu \mathrm{m}$ ESD).

\subsection{Effects of environmental parameters on feeding activity in Haploops nirae}

Environmental parameters seemed to be of unequal importance in affecting Haploops feeding behavior. We chose to test three ecologically important parameters that are classically integrated in numerical models designed to estimate grazing impact of filter-feeders (see for example Cugier et al. 2010): the current velocity, the food concentration (Chl a) and the turbidity (PIM). Numerical models of South Brittany (e.g. see Tessier, 2006 for flow speed and turbidity, and Gohin et al. 2003 for Chl a values) showed that the tested experimental conditions approximated those from the field. However, the maximal turbidity value (e.g. $\left.85.6 \mathrm{mg} . \mathrm{L}^{-1}\right)$ corresponds classically to very estuarine conditions and occurred in rare cases during winter storm and the maximum $\mathrm{Chl}$ a value (e.g. $121.5 \mu \mathrm{g} . \mathrm{L}^{-1}$ ) corresponds to unexpected values in South Brittany where spring phytoplanktonic blooms only result in Chl a values between 10 and $20 \mu \mathrm{g} . \mathrm{L}^{-1}$. Parameters were tested separately, so that the importance of each parameter on the feeding ecology of Haploops can be distinguished, despite obvious possible co-variations in natural environments (e.g. turbidity and flow speed).

The experiments revealed that the current velocity did not have a strong effect on Haploops

425 feeding behavior (Fig. 6). Based on literature, it was expected that flow speed could trigger some changes in feeding behavior, as reported for spionid polychaetes (Taghon et al., 1980; Hentschel and Larson, 2005) or other crustaceans such as porcelain crabs Porcellana longicornis (Achituv and Pedrotti, 1999) or barnacles Semibalanus balanoides (Trager et al., 1990), which actively beat their cirri at low current speeds (active suspension-feeding) but

430 hold them passively extended at high current speed (passive suspension-feeding). This behavior allows organisms not to waste energy in actively collecting particles when the flow is passively bringing food particles to the collecting organs. Haploops however seemed to not obey this general behavior for crustacean suspension-feeders (Riisgård and Larsen, 2010) since their beat frequency for A1 and A2 increased with flow speed. It is worth noticing the 435 large difference between A1 and A2 beat frequency: A2 was generally 4 to 9 times faster than A1 and responded more rapidly to changes in environmental parameters (Tables 4 to 6). In

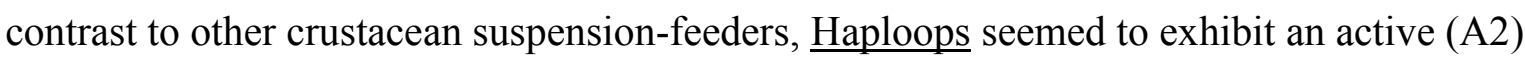
and a passive (A1) feeding behavior at the same time. The current speed did not have an effect on the time individuals spent filtering either: while the number of feeding events 
440 decreased, the time of each feeding event increased. A large inter-individual variability was also reported for this experiment, supporting the idea that flow speed is not of primary importance in stimulating foraging behavior in Haploops.

The concentration of organic (POM) or inorganic (PIM) particles seemed to have similar effects on Haploops feeding behavior. Both PIM and POM increases lead to an exponential increase in the total number of filtering individuals (Figs. 7 and 8). As for POM, the threshold to reach the plateau is very rapid $\left(\mathrm{Chl} \underline{\mathrm{a}}=13.5 \mu \mathrm{g} . \mathrm{L}^{-1}\right)$ but actually corresponds to Chl $a$ values of a late planktonic bloom on the South Brittany coast (Gohin et al. 2003). Below this value, only $20 \%$ of Haploops individuals were actively filtering in a Chl a range indicative of the South Brittany coast for most of the year. This leads to the conclusion that

450 Haploops are not very sensitive to variations in low food concentration but rapidly respond to phytoplankton blooms. Haploops individuals respond to an increase in food concentration by spending more time filtering and greatly increasing the mean time of filtration events. The beat frequency also increased As for PIM, the maximum percent of filtering individuals is reached for PIM $=7.3 \mathrm{mg} . \mathrm{L}^{-1}$, 455 which is a common value for muddy habitats colonized by Haploops nirae. Effects of inorganic matter on suspension-feeding activity are relatively well documented for bivalves (e.g. Barillé et al., 1997; Sobral and Widdows, 2000) and gastropods (Barillé et al., 2006) or for polychaetes (e.g. Hentschel and Larson, 2005; Dubois et al., 2009) but there is no equivalent literature on crustaceans in general and amphipods in particular. Studies in other

460 taxonomic groups have revealed a complex set of physiological and morphological adaptations to seston variability. Small inorganic particles are known to clog filters (cnenidial filters or tentacles), hence drastically reducing the clearance rate and affecting retention efficiencies (see references above). Haploops individuals seemed to be highly stimulated even at low PIM concentrations. Also, the mean time individuals spent filtering increased along with the number of individual filtration events, but not the mean time of a filtration event (except one significant difference between 7.3 and $11.0 \mathrm{mg} \cdot \mathrm{L}^{-1}$ ). This behavior of numerous withdrawings in the tube is probably an adaptation to turbid environments, allowing the amphipod to increase the time filtering and to fully clear the antennae with its pereopods (and to reject pseudofeces pellets, as observed with videos). Haploops individuals are hence able to feed in turbid conditions, even if the food is diluted by inorganic matter, and to collect enough organic matter to cover their needs. We also suggest that the presence of a non-rigid sensory filament close to each setae is a mechanism that triggers the withdrawal of an individual into its tube when several filaments are being clogged by particles. The clogging 
is also limited by the distance between two bristles (ca. $20 \mu \mathrm{m}$ ) corresponding to the particles efficiently retained by Haploops antennae. For the amphipod Corophium volutator, Møller and Riisgård (2006) showed that the distance between two brittles on the gnathopods (filter organs) corresponds to the particle diameter retained with $100 \%$ efficiency (i.e. 6-7 $\mu \mathrm{m}$ ). But even if $\underline{\mathrm{C}}$. volutator colonizes intertidal mudflats, this species lives in a burrow and uses its pleopods to create a current. Haploops antennae are directly out in the water column without any other protection, except withdrawing in its tubes. One can easily imagine than longer and closer bristles on setae would increase the antennae clogging speed.

\subsection{Clearance rate in Haploops nirae and grazing impact at ecosystem level}

485 The calculation of clearance rate (CR) can be biased by particles not retained by feeding organs and this bias increases with seston concentration (see details on CR calculations in Barrillé et al., 1993). CRs were systematically lower with a high standard deviation when taking into account the entire ESD range, in comparison when using the $20-40 \mu \mathrm{m}$ size range, corresponding to the particles retained with $100 \%$ efficiency. A mean CR of $1.06 \pm 0.14$ L.h ${ }^{-1}$ was then calculated for each Haploops core, corresponding to a mean individual CR of $14.6 \pm 0.4 \mathrm{~mL} . \mathrm{h}^{-1}$ (for a $7.2 \pm 0.78 \mathrm{~mm}$ individual) and a standardized CR of $25.2 \pm 0.7$ L.h ${ }^{-1} \cdot g^{-1}$ dry meat weight. To our knowledge, the only study dealing with filtration in amphipods showed that mean individual filtration rate in Corophium volutator was $64 \pm 5.9$ $\mathrm{mL} . \mathrm{h}^{-1}$ for $6.3 \pm 0.21 \mathrm{~mm}$ individuals (Møller and Riisgård, 2006). This value, while slightly above our results, falls within the same range of CRs even if clearance experiments were conducted in closed systems using exponential decrease in algal concentration. When using

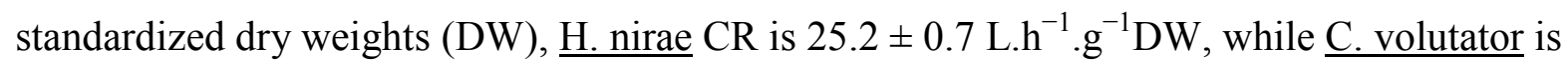
47.2 L.h ${ }^{-1} \cdot \mathrm{g}^{-1} \mathrm{DW}$. One of the main differences between those two amphipod models was the

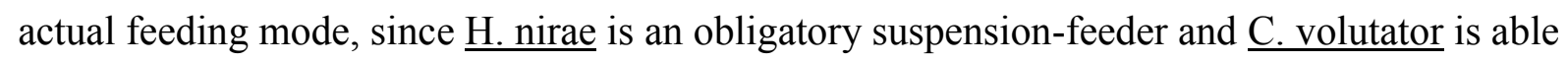
to switch between deposit- and suspension-feeding (Riisgård and Schotge, 2007). Another difference is that the ratio of the total weight to the weight of the feeding organs is smaller in

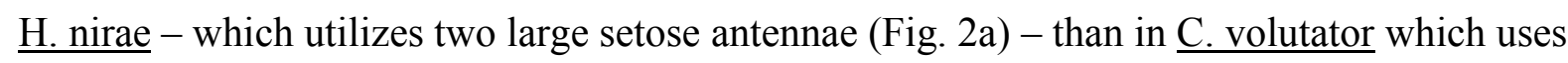
only collecting fans formed by setae on the second gnathopod. This probably means that if

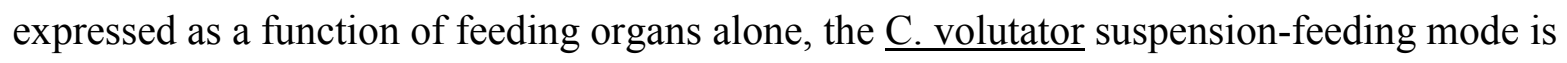
more efficient (i.e. capable of straining a larger volume of water per unit time) than $\underline{H}$. nirae. Weight-standardized CRs of amphipods are much higher than those reported for suspensionfeeders in other taxonomic groups such as bivalves (CR of $\underline{\text { Crassostrea gigas }}=4.2 \mathrm{~L} \cdot \mathrm{h}^{-1} \cdot \mathrm{g}^{-1}$; 
Ropert and Goulletquer, 2000), gastropods (CR of Crepidula fornicata $=0.76 \mathrm{~L} \cdot \mathrm{h}^{-1} \cdot \mathrm{g}^{-1}$; Barillé et al. 2006) or polychaetes (CR of $\underline{\text { Sabellaria alveolata }}=0.35 \mathrm{~L} \cdot \mathrm{h}^{-1} \cdot \mathrm{g}^{-1}$; Dubois et al., 2009). In numerous ecosystems where ampeliscid amphipods colonize large areas, dense tube mats and 'lawns' of feeding appendages can potentially have significant grazing impact on phytoplankton and on food web functioning (Sheader, 1998). However, while studies have demonstrated effects of Ampelisca mats on sediment remodeling and subsequent sediment stabilization and geochemical process (Diaz et al., 2008) or enhancement of associated species (Mackenzie et al., 2006), there is no quantitative evaluation of suspension-feeding pressure of amphipod mats. In a modeling approach designed to evaluated grazing impact by most dominant filter-feeding species in Odense Fjord, Riisgård et al. (2007) estimated that

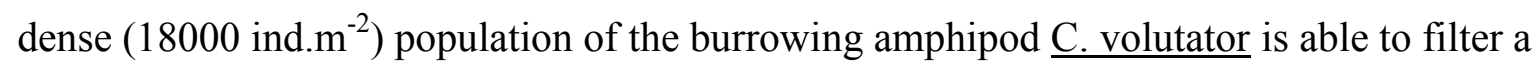
volume of water equivalent to the entire column of about 25 times per day. In South Brittany

520 (France), shallow coastal ecosystems are mainly composed of soft-bottom communities ranging from slightly muddy sandy communities to muddy communities and recent mappings involving acoustic side-scan sonar approach, Ehrhold et al., (2006, 2007, 2008), revealed that $\underline{\text { H. nirae }}$ was spreading over large areas in the bay of Concarneau (over ca. 3000 hectares) and in the bay of Vilaine (over ca. 7500 hectares). Using core samples, mean densities were estimated at 9950 ind. $\mathrm{m}^{-2}$ in the bay of Concarneau $\left(\min =3160 ; \max =22050\right.$ ind. $\left.\mathrm{m}^{-2}\right)$ and 9820 ind. $\mathrm{m}^{-2}$ in the bay of Vilaine $\left(\min =1300 ; \max =18000\right.$ ind. $\left.\mathrm{m}^{-2}\right)$ (Rigolet, Unpublished results). CRs values obtained for Haploops cores were considered representative of the entire habitat and were then extrapolated to each colonized area. Grazing impact of $\underline{H}$. nirae is estimated to be $189.3 \mathrm{~L} \cdot \mathrm{h}^{-1} \cdot \mathrm{m}^{-2}$ and hence $13610^{6} \mathrm{~m}^{3} \cdot \mathrm{day}^{-1}$ in the bay of Concarneau and 340 $53010^{6} \mathrm{~m}^{3}$.day ${ }^{-1}$ in the bay of Vilaine. By using the numerical model MARS-3D (Lazure and Dumas, 2008), we estimated the time needed for the Haploops to filter a volume of water equivalent to the entire column is 4-5 days (assuming efficient vertical mixing and a water column height calculated for a mean tide) and the time needed to filter a volume of water equivalent to the whole bay of Concarneau or Vilaine is 29-30 days. Even if the grazing

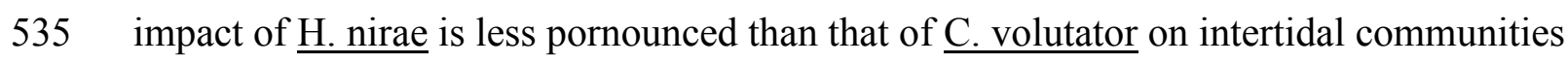
(Riisgård et al., 2007), this study provides here evidences that tubiculous amphipod communities play a significant role in the food web within the ecosystem they colonize. Further regression or extension in Haploops communities are hence likely to adversely affect the balance of the coastal trophic web. 
Acknowledgements

We would like to thank Dr. M. Alunno-Bruscia for providing us access to experimental facilities in the Marine Station of Argenton, as well as I. Queau, L. Lebrun and J. Quere for providing all the microalgae species. We thank P. Crassous for his help with the scanning electron microscope, A. Severe for her help in histological preparations, and C.G. Gelpi (Louisiana State University) for his help in English editing. S.F.D. was funded by a grant from the EC2CO National Program on Coastal Environments and by the Total Foundation for Biodiversity and the Sea and C.R. was funded by a PhD grant of Ifremer and Region Bretagne.

\section{References}

Achituv, Y., Pedrotti, M.L., 1999. Costs and gains of porcelain crab suspension feeding in different flow conditions. Mar. Ecol. Prog. Ser. 184, 161-169.

Barillé, L., Cognie, B., Beninger, P., Decottignies, P., Rincé, Y., 2006. Feeding responses of the gastropod Crepidula fornicata to changes in seston concentration. Mar. Ecol. Prog. Ser. 322, 169-178.

Barillé, L., Prou, J., Héral, M., Bougrier, S., 1993. No influence of food quality, but rationdependent retention efficiencies in the Japanese oyster Crassostrea gigas. J. Exp. Mar. Biol. Ecol. 171, 91-106.

Barillé, L., Prou, J., Héral, M., Razet, D., 1997. Effects of high natural seston concentrations on the feeding, selection, and absorption of the oyster Crassostrea gigas (Thunberg). J. Exp. Mar. Biol. Ecol. 212, 149-172.

Bellan-Santini, D., Dauvin, J.C., 1989. Vertical distribution and biogeographic repartition of the holobenthic filter-feeders crustacean. An example, the genus Ampelisca 
(Amphipoda), a zoological group with a high level of speciation. Bull. Soc. Geol. Fr. $5,561-568$.

Beninger, P.G., Potter, T.M., St-Jean, S.D., 1995. Paddle cilia fixation artefacts in pallial organs of adult Mytilus edulis and Placopecten magellanicus (Mollusca : Bivalvia). Can. J. Zool. 73, 610-614.

Beninger, P.G., St-Jean, S., 1997. Particle processing on the labial palps of Mytilus edulis and Placopecten magellanicus (Mollusca: Bivalvia). Mar. Ecol. Prog. Ser. 147, 117-127.

Beninger, P.G., St-Jean, S., Poussart, Y., Ward, J.E., 1993. Gill function and mucocyte distribution in Placopecten magellanicus and Mytilus edulis (Mollusca: Bivalvia). Mar. Ecol. Prog. Ser. 98, 275-282.

Boyde, A., Wood, C., 1969. Preparation of animal tissues for surface-scanning electron microscopy. J. Micr. 90, 221-249.

Cugier, P., Struski, C., Blanchard, M., Mazurie, J., Pouvreau, S., Olivier, F., Trigui, J.R., Thiébaut, E., 2010. Assessing the role of benthic filter feeders on phytoplankton production in a shellfish farming site: Mont-Saint-Michel Bay, France. J. Mar. Syst. $82,21-34$

585 Dauvin, J.C., Bellan Santini, D., 1990. An overview of the Amphipod genus Haploops (Ampeliscidae). J. Mar. Biol. Ass. U.K. 70, 887-903.

Dauvin, J.C., Bellan Santini, D., 1996. Ampeliscidae (Amphipoda) from the Bay of Biscay. J. Crust. Biol. 16, 149-168.

Dauvin, J.C., Zouhiri, S., 1996. Suprabenthic crustacean fauna of a dense Ampelisca community from the English Channel. J. Mar. Biol. Ass. U.K. 76, 909-929.

Diaz, R.J., Rhoads, D.C., Blake, J.A., Kropp, R.K., Keay, K.E., 2008. Long-term Trends of Benthic Habitats Related to Reduction in Wastewater Discharge to Boston Harbor. Estuar. Coasts 31, 1184-1197. 
Dubois, S., Barillé, L., Cognie, B., 2009. Feeding response of the polychaete Sabellaria alveolata (Sabellariidae) to changes in seston concentration. J. Exp. Mar. Biol. Ecol. 376, 94-101.

Dubois, S., Barillé, L., Cognie, B., Beninger, P.G., 2005. Particle capture and processing mechanisms in Sabellaria alveolata (Polychaeta : Sabellariidae). Mar. Ecol. Prog. Ser. $301,159-171$.

600 Ehrhold, A., Hamon, D., Guillaumont, B., 2006. The REBENT monitoring network, a spatially integrated, acoustic approach to surveying nearshore macrobenthic habitats: application to the Bay of Concarneau (South Brittany, France). Ices J. Mar. Sci. 63, 1604-1615.

Enequist, P., 1949. Studies in the soft-bottom amphipods of the Skagerrak. Zool. Bidr. Upps. 28, 297-492.

Gohin, F., Lampert, L., Guillaud, J.-F., Herbland, A., Nézan, E., 2003. Satellite and in situ observations of a late winter phytoplankton bloom, in the northern Bay of Biscay. Cont. Shelf Res. 23, 1117-1141.

Göransson, P., 2002. Petersen's benthic macrofauna stations revisited in the Öresund area (southern Sweden) and species composition in the 1990s - signs of decreased biological variation. Sarsia 87(4), 263-280.

Hentschel, B.T., Larson, A.A., 2005. Growth rates of interface-feeding polychaetes: combined effects of flow speed and suspended food concentration. Mar. Ecol. Prog. Ser. 293, 119-129.

615 Hochberg, R., Litvaitis, M.K., 2000. Hexamethyldisilazane for Scanning Electron Microscopy of Gastrotricha. Biotech. Hystochem. 75, 41-44.

Kanneworff, E., 1966. On some amphipod species of the genus Haploops, with special reference to $\underline{H}$. tubicola and $\underline{H}$. tenuis sp. nov. from the Öresund. Ophelia 3, 183-207. 
LeBris, H., Glémarec, M., 1996. Marine and brackish ecosystems of south Brittany (Lorient and Vilaine bays) with particular reference to the effect of the turbidity maxima. Est. Coast. Shelf Sci. 42, 737-753.

Levinton, J.S., 1995. Marine biology: function, biodiversity, ecology. Oxford University Press, New York, 420 pp.

Lincoln, R.J., 1979. British marine Amphipoda: Gammaridea. British Museum (Natural History), London, $658 \mathrm{pp}$.

Mackenzie, C.L., Pikanowski, R., McMillan, D.G., 2006. Ampelisca amphipod tube mats may enhance abundance of northern quahogs Mercenaria mercenaria in muddy sediments. J. Shell. Res. 25, 841-847.

Martoja, R., Martoja, M., 1967. Initiation aux techniques de l'histologie animale. Masson et cie, Paris.

Møller, L.F., Riisgård, H.U., 2006. Filter feeding in the burrowing amphipod Corophium volutator. Mar. Ecol. Prog. Ser. 322, 213-224.

Riisgård, H.U., 2001. On measurement of filtration rates in bivales - the stony road to reliable data: review and interpretation. Mar. Ecol. Prog. Ser. 211, 275-291.

635 Riisgård, H.U., Schotge, P., 2007. Surface deposit-feeding versus filter-feeding in the amphipod Corophium volutator. Mar. Biol. Res. 3, 421-427.

Riisgård, H.U., Larsen, P.S., 2010. Particle capture mechanisms in suspension-feeding invertebrates. Mar. Ecol. Prog. Ser. 418, 255-293.

Riisgård, H.U., Lassen, J., Kortegaard, M., Møller, L.F., Friedrichs, M., Jensen, M.H., Larsen, P.S., 2007. Interplay between filter-feeding zoobenthos and hydrodynamics in the shallow Odense Fjord (Denmark) - Earlier and recent studies, perspectives and modelling. Est. Coast. Shelf Sci. 75, 281-295. 
Shillaker, R.O., Moore, P.G., 1978. Tube building by the amphipods Lembos websteri (Bate) and Corophium bonnelii (Milne Edwards). J. Exp. Mar. Biol. Ecol. 33, 169-185.

645 Shyamasundari, K., Rao, K.H., 1977. Studies on the alimentary canal of Amphipods: morphology and histology of cephalic mucous glands. Crustaceana 33, 149-152. Sobral, P., Widdows, J., 2000. Effects of increasing current velocity, turbidity and particlesize selection on the feeding activity and scope for growth of Ruditapes decussatus from Ria Formosa, southern Portugal. J. Exp. Mar. Biol. Ecol. 245, 111-125.

650 Taghon, G.L., Nowell, A.R.M., Jumars, P.A., 1980. Induction of suspension feeding in spionid polychaetes by high particulate fluxes. Science 210, 562-564.

Teissier, C., 2006. Caractérisation et dynamique des turbidités en zone côtière: l'exemple de la région marine Bretagne Sud. $\mathrm{PhD}$ thesis University of Bordeaux, $428 \mathrm{pp}$.

Trager, G.C., Hwang, J.S., Strickler, J.R., 1990. Barnacle suspension-feeding in variable flow. Mar. Biol. 105, 117-127.

Wildish, D.J., Dickinson, J.J., 1982. A new species of Haploops (Amphipoda, Ampeliscidae) from the Bay of Fundy. Can J. Zool. 60, 962-967.

660 


\section{Figure captions}

Fig. 1. Details of an experimental trough designed to contain a core of sediment colonized by Haploops nirae. An adjustable bottom mounted on a screw allows pushing up the sediment core, so that the surface reaches a plate used as the bottom of the measurement chamber. The flow in the measurement chamber is unidirectional and there is no connection between the two compartments hence created by the plate.

Fig. 2. Scanning electron micrographs (A-C) and microscope photographs (D-E) of Haploops nirae. (A) Whole individual (adult) showing the two long pairs of antennae (arrow). (B) Close-up of the median portion of antennae showing groups of setae bearing small setules. (C) Close-up of the insertion area of setae on antennae. Note the presence of a non-rigid sensory filament (arrow) at each insertion point of setae. (D) Longitudinal section of the thoracic region showing the propodus $(\mathrm{Pr})$, the merus $(\mathrm{Me})$, the basis $(\mathrm{Ba})$ and the coxal plate

680 (Co) of the gnathopod 2. Note the large acid mucous gland revealed by Alcian-Blue (arrow).

(E) Whole-mount of antennae stained with Alcian-Blue revealing acid mucous on the antennae surface. (F) Close-up of the median portion of Ampelisca spinipes antennae showing setae. Note the absence of setule on the setae (arrow).

685 Fig. 3. Example of particle size spectra (expressed as particle volume) of the experimental diet at the inflow and the outflow of the experimental troughs. (a) Isochrysis galbana peak, (b) Skeletonema costatum peak, (c) Thalassiosira weissflogii peak and (d) Scrippsiella trochoidea peak. Note that outflow particle volumes are larger than inflow in this example, because of Haploops individual resuspension activity.

Fig. 4. Retention efficiency of Haploops nirae for the tested experimental diet.

Fig. 5. Variations in clearance rates calculated for the three troughs and the mean of the three troughs (black bars) after 60, 90 and 180 minutes. No significant differences were shown in mean clearance rates according to time and between the troughs.

Fig. 6. Effect of current velocity $\left(\mathrm{cm} \cdot \mathrm{s}^{-1}\right)$ on the number of filtering individual (\%). No nonlinear regression model was statistically valid. 
700 Fig. 7. Effect of food concentration ( $\left.\mu \mathrm{g} \mathrm{Chl} \mathrm{a.} \mathrm{L}^{-1}\right)$ on the number of filtering individual (\%). A non-linear model was fitted to the experimental values. Adjusted $r^{2}=0.925$.

Fig. 8. Effect of particulate inorganic matter $\left(\mathrm{mg}\right.$ kaolinite. $\left.\mathrm{L}^{-1}\right)$ on the number of filtering individual (\%).A non-linear model was fitted to the experimental values. Adjusted $\mathrm{r}^{2}=0.945$. 705 


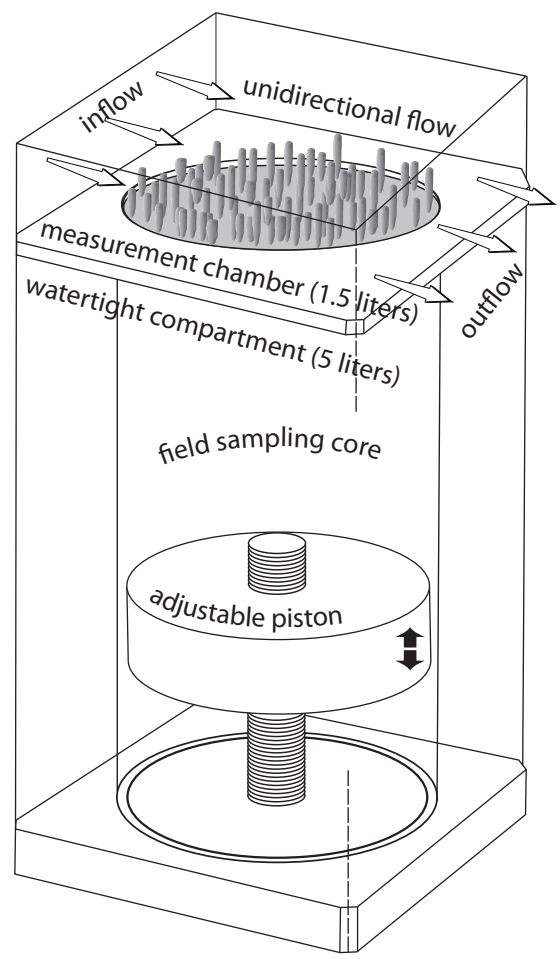



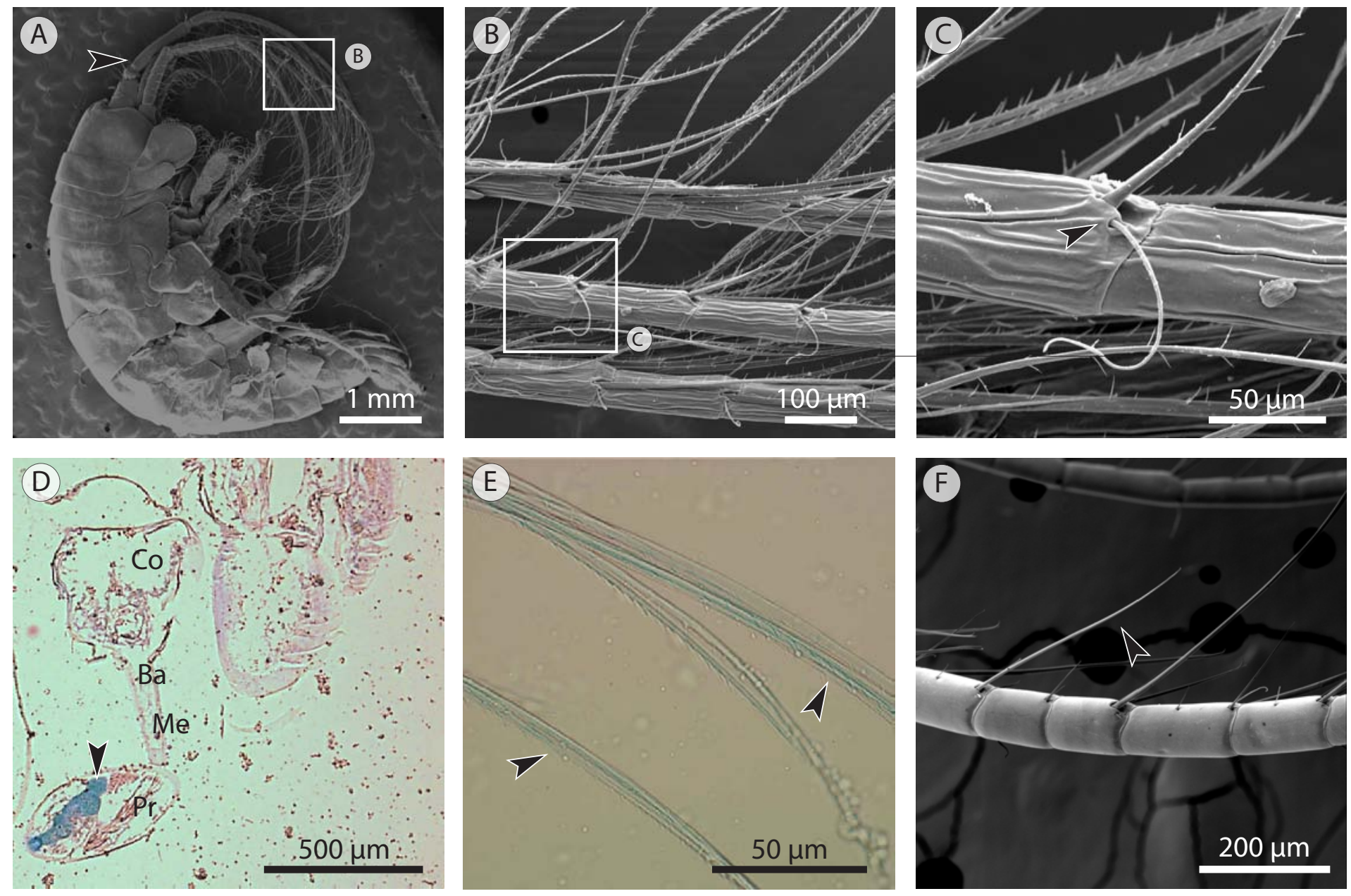

intended for color reproduction on the web and in print 


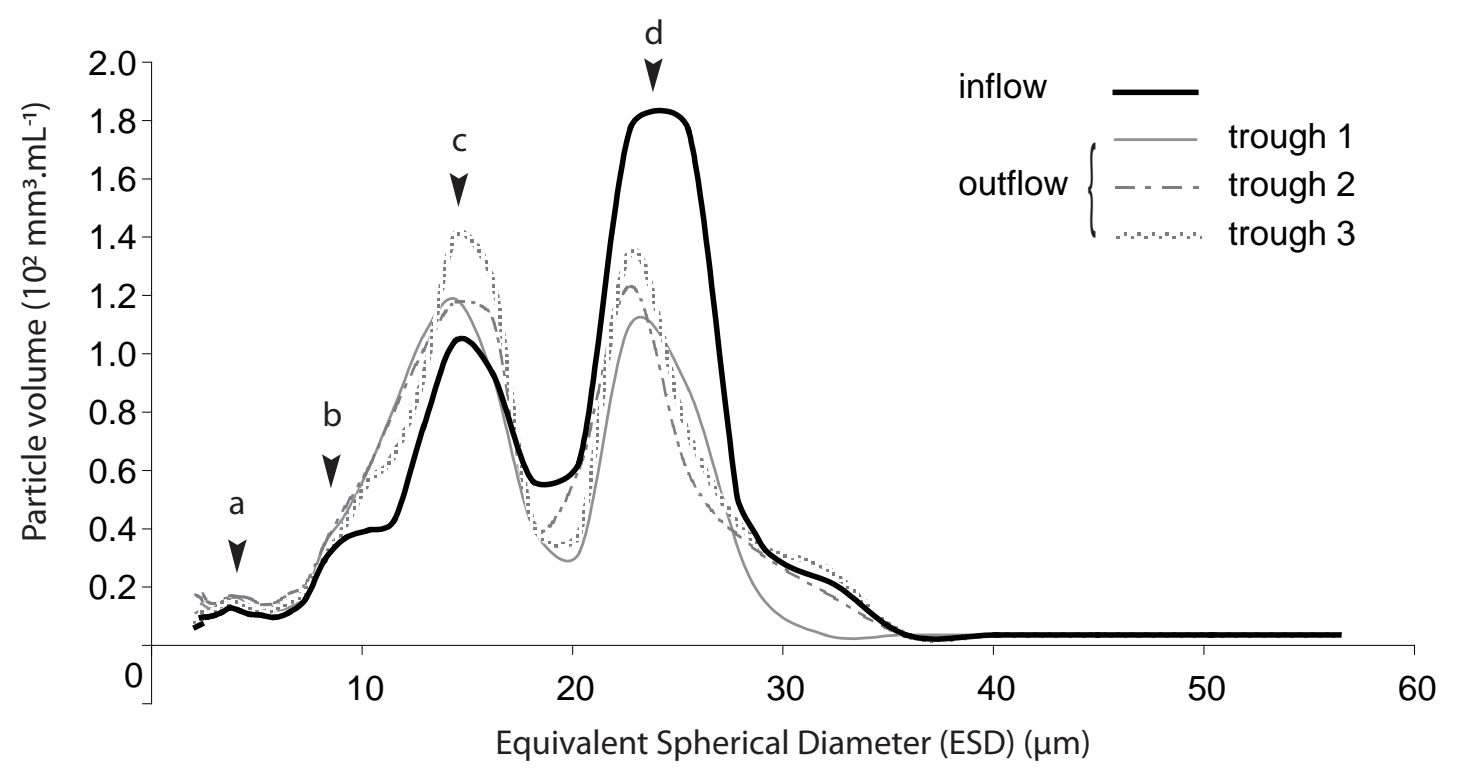




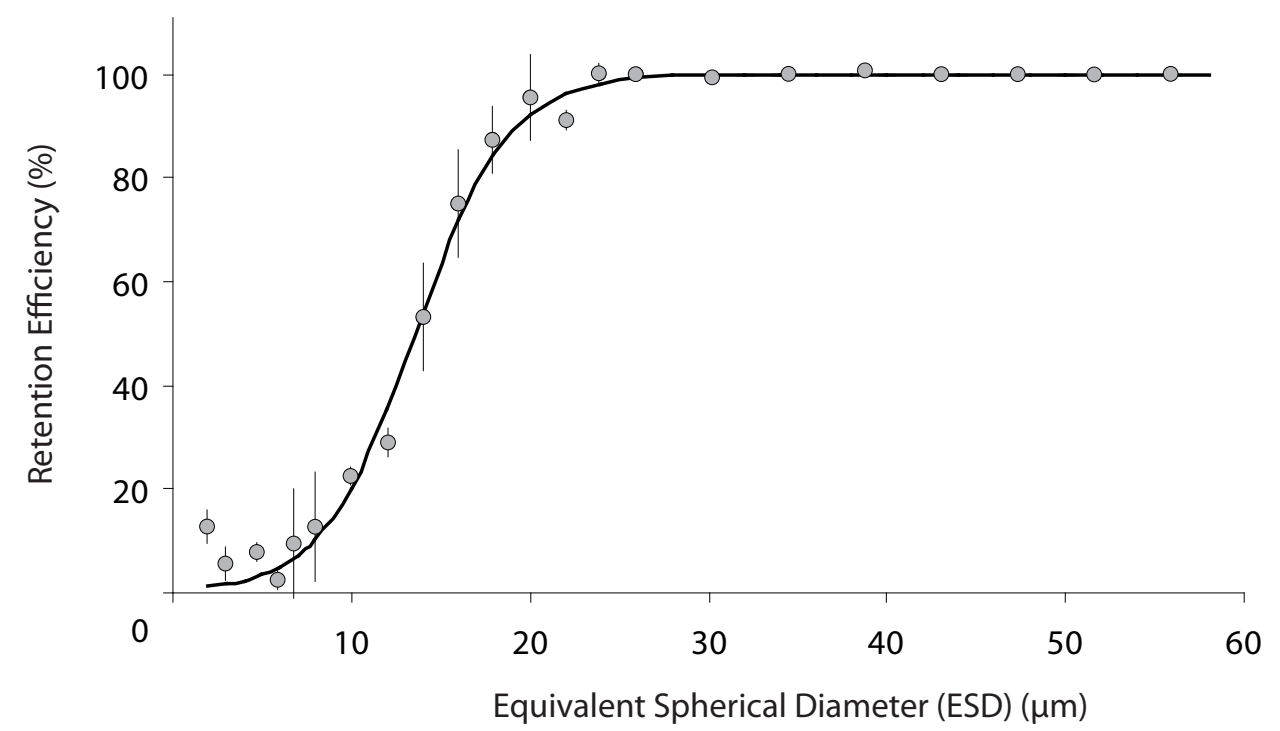

Equivalent Spherical Diameter (ESD) $(\mu \mathrm{m})$ 
Figure5

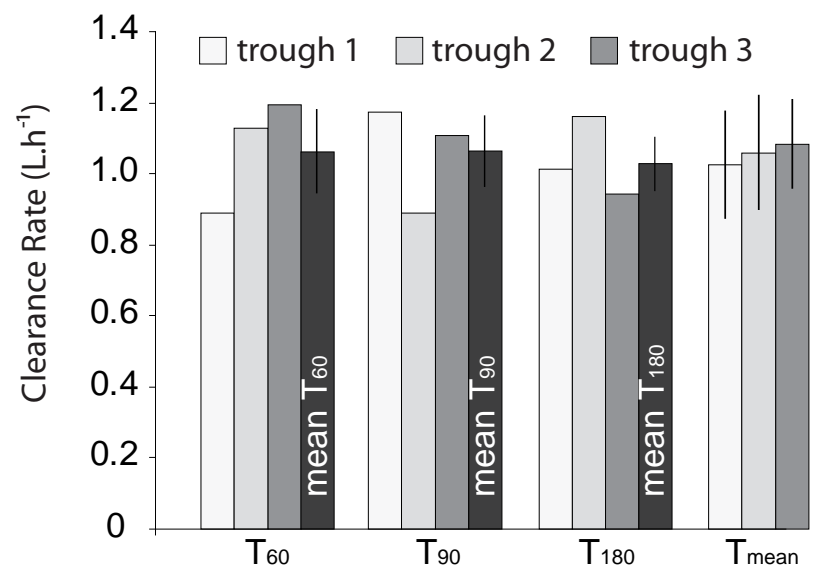


Figure6

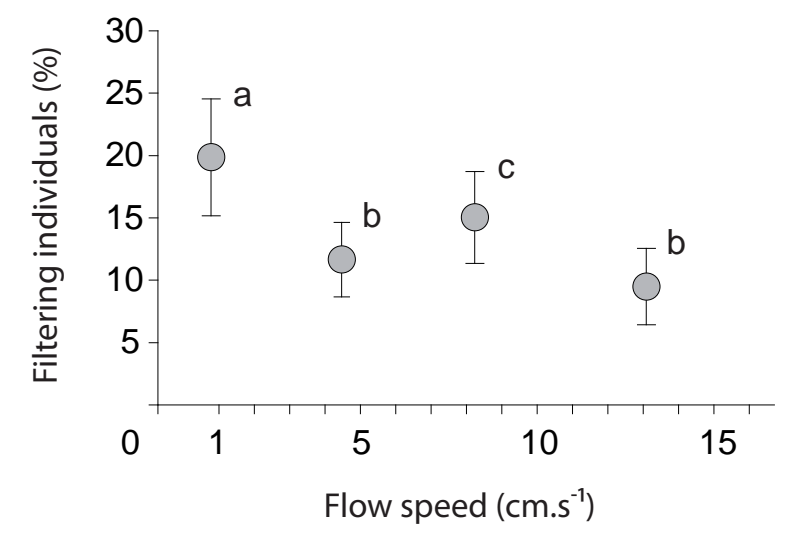

Flow speed $\left(\mathrm{cm} . \mathrm{s}^{-1}\right)$ 
Figure7

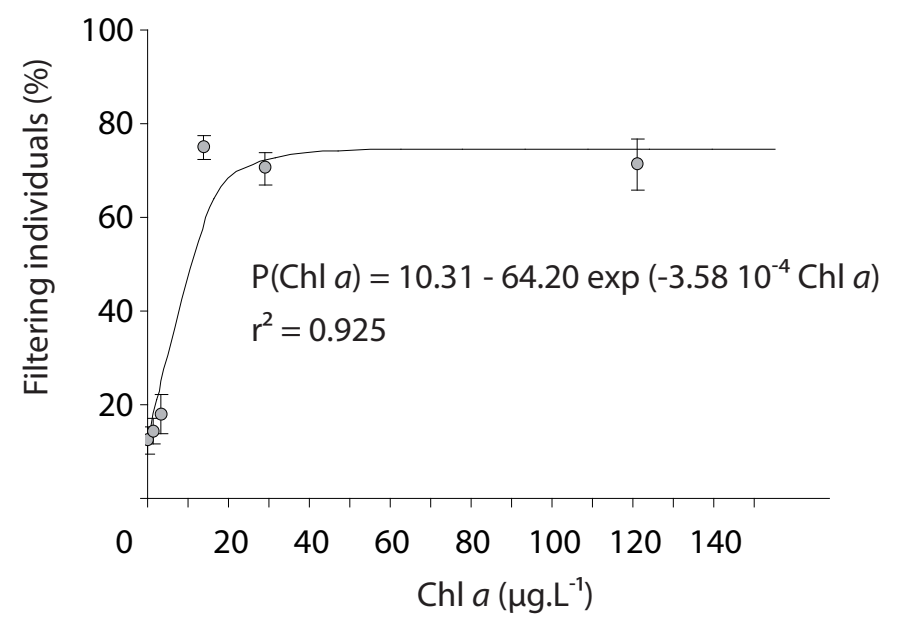


Figure8

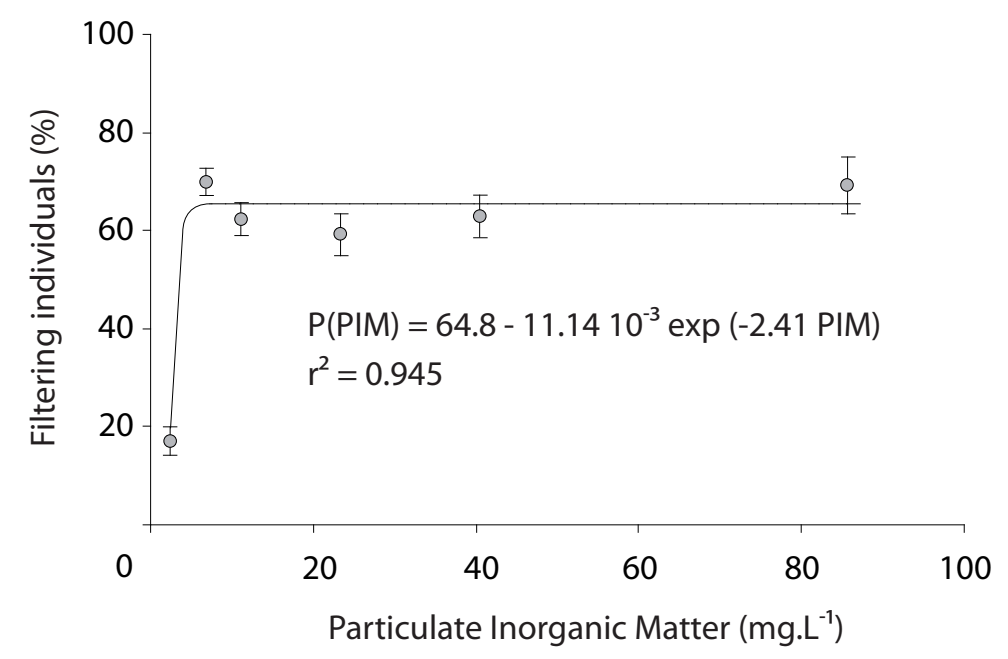




\section{Table 1}

Composition of the experimental diet. Microalgae were cultivated separately at the Experimental Marine Station of Argenton (IFREMER) and mixed before supplied to Haploops nirae individuals. Sizes (in ESD) were determined from pure culture algae using the particle counter.

\begin{tabular}{lcccc}
\hline Species & Family & Class & $\begin{array}{c}\text { Min-Max Size } \\
(\mu \mathrm{m})\end{array}$ & $\begin{array}{c}\text { Mode } \\
(\mu \mathrm{m})\end{array}$ \\
\hline Isochrysis galbana (Parke) & Isochrysidaceae & Prymnesiophyceae & $3-6$ & 4 \\
Skeletonema costatum (Greville) & Skeletonemaceae & Mediophyceae & $4-10$ & 6 \\
Thalassiosira weissflogii (Grunow) & Thalassiosiraceae & Mediophyceae & $9-17$ & 12 \\
Scrippsiella trochoidea (Stein) & Peridiniaceae & Dinophyceae & $20-40$ & 27 \\
\hline
\end{tabular}




\section{Table 2}

Environmental parameters and conditions used to test for the feeding activity of Haploops nirae.

\begin{tabular}{|c|c|c|}
\hline Parameters & Conditions & Comments \\
\hline Current velocity $\left(\mathrm{cm} \cdot \mathrm{s}^{-1}\right)$ & $0.8 / 4.4 / 8.2 / 13.1$ & $\begin{array}{c}\text { Concentration in } \underline{\mathrm{T} . \text { weissflogii }} \\
10^{4} \text { cell. } \mathrm{mL}^{-1}\end{array}$ \\
\hline $\begin{array}{l}\text { Food concentration (Chl. } \underline{\mathrm{a}} \text { in } \\
\left.\mu \mathrm{g} . \mathrm{L}^{-1}\right)\end{array}$ & $0 / 1.3 / 2.1 / 13.5 / 27.0 / 121.5$ & Flow rate $=3.5 \mathrm{~L} \cdot \mathrm{h}^{-1}\left(1.23 \mathrm{~cm} . \mathrm{s}^{-1}\right)$ \\
\hline $\begin{array}{l}\text { Concentration in inorganic } \\
\text { matter }(\mathrm{PIM})\left(\mathrm{mg} \cdot \mathrm{L}^{-1}\right)\end{array}$ & $2.3 / 7.3 / 11.0 / 23.3 / 40.5 / 85.5$ & $\begin{array}{c}\text { Concentration in } \underline{T} \text {. weissflogii } \\
10^{4} \text { cell. } \mathrm{mL}^{-1} \text { and flow rate }=3.5 \\
\text { L. } \mathrm{h}^{-1}\end{array}$ \\
\hline
\end{tabular}




\section{Table 3}

Effect of current velocity $\left(\mathrm{cm} . \mathrm{s}^{-1}\right)$ on feeding activity parameters of Haploops nirae individuals. Results are mean $\pm \mathrm{SE}, \mathrm{n}=15$ individuals randomly selected. When significant, global p-level are mentioned as $*=\mathrm{p}<0.05 ; * *=\mathrm{p}<0.01 ; * * * \mathrm{p}<0.001$. Results of posthoc comparisons are represented by superscript letters, two similar letters indicating nonsignificant variation.

\begin{tabular}{lccccc}
\hline Current velocity $\left(\mathbf{c m . \mathbf { s } ^ { - 1 }}\right)$ & $\mathbf{0 . 8}$ & $\mathbf{4 . 4}$ & $\mathbf{8 . 2}$ & $\mathbf{1 3 . 1}$ & p-level \\
\hline Mean individual time spent filtering (\%) & $20.9 \pm 4.3$ & $9.0 \pm 2.7$ & $13.6 \pm 3.2$ & $11.1 \pm 1.8^{2}$ & $\mathrm{p}=0.111$ \\
Mean individual number of filtration events & $23.7 \pm 2.8^{\mathrm{a}}$ & $12.1 \pm 3.0^{\mathrm{b}}$ & $10.1 \pm 2.1^{\mathrm{b}}$ & $10.2 \pm 1.3^{\mathrm{b}}$ & $* *$ \\
Mean time of filtration events (min) & $5.7 \pm 0.7^{\mathrm{ab}}$ & $4.7 \pm 0.4^{\mathrm{b}}$ & $9.6 \pm 0.7^{\mathrm{c}}$ & $7.8 \pm 1.2^{\mathrm{bc}}$ & $* *$ \\
A1 antennae beat frequency $\left(\mathrm{min}^{-1}\right)$ & $2.7 \pm 0.7^{\mathrm{a}}$ & $4.7 \pm 1.3^{\mathrm{ab}}$ & $7.7 \pm 1.3^{\mathrm{b}}$ & $7.1 \pm 1.1^{\mathrm{b}}$ & $*$ \\
A2 antennae beat frequency $\left(\mathrm{min}^{-1}\right)$ & $18.5 \pm 0.7^{\mathrm{a}}$ & $27.1 \pm 1.8^{\mathrm{b}}$ & $30.3 \pm 2.6^{\mathrm{b}}$ & $27.8 \pm 2.3^{\mathrm{b}}$ & $* *$ \\
\hline
\end{tabular}




\section{Table 4}

Effect of particulate organic matter, measured as concentration in Chl. $\underline{a}\left(\mu \mathrm{g} . \mathrm{L}^{-1}\right)$ on feeding activity parameters of Haploops nirae individuals. Results are mean $\pm \mathrm{SE}, \mathrm{n}=15$ individuals randomly selected. When significant, global $\mathrm{p}$-level are mentioned as $*=\mathrm{p}<0.05 ; * *=\mathrm{p}<$ $0.01 ; * * * \mathrm{p}<0.001$. Results of post-hoc comparisons are represented by superscript letters, two similar letters indicating non-significant variation.

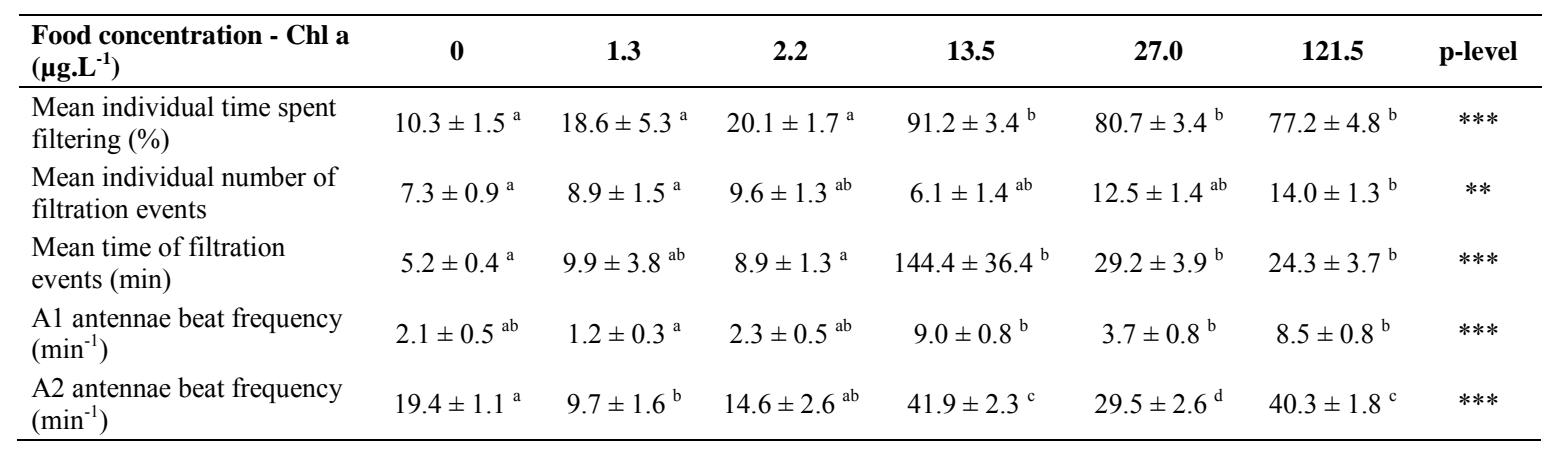




\section{Table 5}

Effect of particulate inorganic matter $\left(\mathrm{mg}^{\mathrm{L}} \mathrm{L}^{-1}\right)$ on feeding activity parameters of Haploops

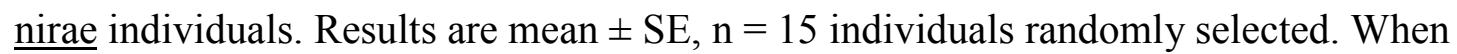
significant, global p-level are mentioned as $*=\mathrm{p}<0.05 ; * *=\mathrm{p}<0.01 ; * * * \mathrm{p}<0.001$. Results of post-hoc comparisons are represented by superscript letters, two similar letters indicating non-significant variation. $\mathrm{NA}=$ no results.

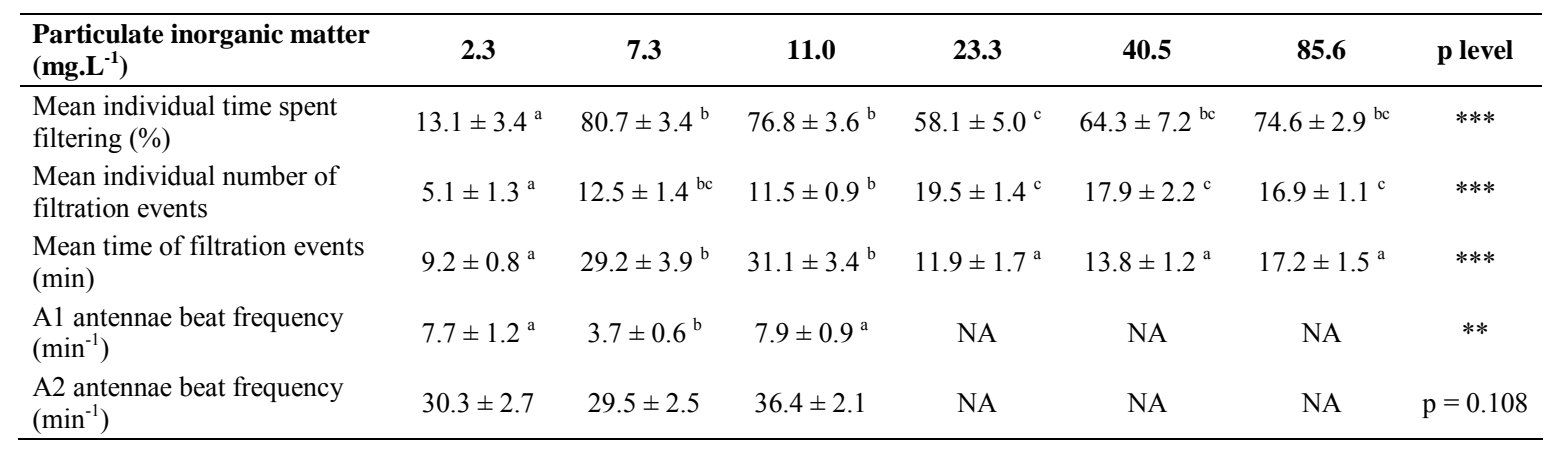

